\title{
INTERRELASI FUNDAMENTALISME DAN ORIENTASI IDEOLOGI GERAKAN ISLAM KONTEMPORER
}

\author{
Ahmad Nur Fuad*
}

\begin{abstract}
A bstract: This article deals with the interrelation between Islamic fundamentalism and other ideological orientations of contemporary Islamist movements, such as Islamism, revivalism, radicalism, salafism, and political Islam. It tries to explore the similarities in their characteristics as well as their differences in the focuses and strategies of the movements. This articles argues that these Islamist movements express their ideological aspirations in different ways: some try to build an Islamic state or even a universal Islamic caliphate (political Islam), while others emphasize much more on the implementation of shari'ah in the level of individuals and society, apart from state (salafis). However, they did not succeed yet in transforming the political landscape of the Muslim world in accordance with their ideological framework.
\end{abstract}

Keywords: fundamentalism; political Islam; radicalism; neo-fundamentalism.

\section{Pendahuluan}

Sebagai ideologi gerakan Islam kontemporer, fundamentalisme mewujudkan diri dalam beragam bentuk, dan berkaitan erat dengan orientasi ideologi lain, seperti revivalisme, Islamisme (neo-fundamentalisme) dan radikalisme. Sekalipun pada mulanya fundamentalisme lebih menunjukkan watak keagamaan, ia kemudian lebih dipahami sebagai bentuk ekspresi Islam yang berdimensi politik. Hal ini mudah dipahami karena dalam perkembangannya fundamentalisme mewujudkan diri dalam bentuk kegiatan atau gerakan politik, yang bahkan seringkali bersifat radikal atau militan, melawan rejim penguasa sekular, atau berjuang untuk membangun sistem kenegaraan yang didasarkan pada shariłah (Islam).

Meskipun istilah fundamentalisme, revivalisme, Islamisme dan radikalisme sering digunakan secara bergantian untuk tujuan penyederhanaan (simplifikasi), kebanyakan sarjana mencoba melakukan identifikasi terhadap karakteristik masing-masing gerakan atau orientasi ideologinya. Para sarjana, seperti akan disebutkan, biasanya merujuk kepada gerakan-gerakan atau pemikirpemikir M uslim yang memiliki kaitan dan afiliasi dengan gerakan Islam kontemporer tertentu di dunia Islam, seperti kawasan Timur Tengah, Afrika Utara, Indo-Pakistan dan Asia Tenggara. Mereka menemukan adanya beberapa karakteristik umum (common characteristics) sekaligus keunikan (peculiarities) dari pelbagai gerakan fundamentalisme Islam.

Tulisan ini memfokuskan kajian pada karakteristik dasar fundamentalisme, dan interrelasi antara fundamentalisme, revivalisme, Islamisme, dan radikalisme. Tulisan ini berusaha menunjukkan adanya kemiripan karakteristik, agenda dan orientasi antara fundamentalisme Islam dan ideologi keislaman yang lain, sekalipun terdapat beberapa perbedaan dalam tekanan kegiatan dan strategi perjuangan. Di bagian akhir, tulisan ini mencoba memetakan secara garis

\footnotetext{
* Fakultas Adab IAIN Sunan Ampel Surabaya.
} 
besar orientasi ideologi gerakan fundamentalis Islam di Indonesia. Tulisan ini adalah survei pendahuluan terhadap beberapa literatur yang ditulis oleh sarjana tentang fundamentalisme Islam, dan tidak berdasarkan observasi langsung terhadap pelbagai gerakan Islam fundamentalis. Karenanya, tulisan ini lebih bersifat hipotetik.

\section{Taksonomi Orientasi Gerakan Islam}

Berkembangnya beragam varian atau manifestasi keagamaan Islam, terutama gerakan dan pemikiran keislaman, mendorong beberapa sarjana membuattipologi, klasifikasi, atau taksonomi (taxonomy). Dalam Political Islam: Religion and Politics in the Arab World, Nazih Ayubi membuat taksonomi orientasi gerakan Islam: reformisme atau modernisme Islam, salafisme, fundamentalisme, neo-fundamentalisme, Islamisme, dan Islam politik (political Islam). ${ }^{1}$

Menurut Ayubi, reformisme Islam atau modernisme Islam (diwakili antara lain oleh alAfghani dan 'Abduh) berpandangan bahwa Islam adalah sistem keyakinan yang sempurna tetapi cukup fleksibel untuk mengakomodasi perkembangan modern (modernitas). Sementara itu, salafisme menekankan kepada sumber Islam yang otentik (al-Q ur'an, Sunnah Nabi dan tradisi para generasi Muslim awal, salaf). Salafisme cenderung skripturalis dan tradisionalis, seperti direpresentasikan oleh Wahabiłah, Sanusiyah, Mahdiłah, dan ajaran-ajaran yang bersumber dari Rashid Ridł dan tokoh al-Ikhwan al-M uslimun awal, seperti H asan al-Banna. Kaum salafi cenderung kepada dogmatisme doktrinal, meskipun kadangkala secara politik fleksibel. Sedangkan fundamentalisme, hampir sama dengan salafisme, menekankan kepada sumber asli Islam (al-Qur'an dan al-Sunnah), tetapi kurang simpatik terhadap fiqih. Fundamentalisme memegangi pandangan holistik dan komprehensif tentang Islam (intégrisme -Perancis). Islam, menurut fundamentalisme, adalah agama, dunia dan negara (din, dunya $>$ dawlah). Perspektif holistik ini mengimplikasikan keharusan tindakan kolektif untuk mewujudkan totalitas Islam ke dalam kenyataan. ${ }^{2}$

Sementara itu, neo-fundamentalisme Islam adalah sempalan dari ideologi fundamentalisme. Biasanya neo-fundamentalisme memiliki orientasi yang lebih radikal dan militan. Pada umumnya, gerakan neo-fundamentalis cenderung melakukan tindakan langsung sebagai reaksi terhadap suatu kasus tertentu. Contoh dari gerakan model ini adalah Takfiswa al-Hijrah di Mesir dan alJ ihad di Mesir dan beberapa negara Arab. Ayubi menyebutkan bahwa orientasi neofundamentalisme ini lebih bercorak politik. Keanggotaannya terutama terdiri dari mahasiswa atau sarjana baru, dari kawasan urban baru kota besar atau dari kota-kota kecil dengan asal-usul pedesaan (rural). Di Mesir, neo-fundamentalis menguasai organisasi mahasiswa, dan memiliki hubungan dengan kalangan profesional, ahli teknik, dan pegawai pemerintahan. ${ }^{3}$ Saad Eddin Ibrahim menyebut gerakan ini sebagai bentuk militansi Islam (Islamic militancy) yang ia definisikan sebagai "actual violent group behavior committed collectively against the state or other actors in

\footnotetext{
${ }^{1}$ Nazih Ayubi, Political Islam: Religion and Politics in the Arab World (London and New York: Routledge, 1991), 6768.

${ }^{2} \mathrm{Ibid}$.

3 Ibid., 67-68, dan 73.
} 
the name of Islam," ${ }^{4}$ seperti tampak pada J ama'at al-Fanniyah al-'Askariyah (Technical Military Academy) dan al-Takfiswa al-Hijrah. Tentang Islamisme, Ayubi menyebutkan bahwa istilah ini biasanya digunakan untuk menunjuk tiga kategori gerakan Islam: salafi, fundamentalis dan neofundamentalis. Islamisme tidak sekedar menekankan identitas sebagai muslim, tetapi lebih kepada pilihan sadar terhadap Islam sebagai doktrin dan ideologi. ${ }^{5}$ Islam politik (political Islam) sering digunakan untuk merujuk kepada kategori fundamentalis dan neo-fundamentalis yang cenderung menekankan watak politik dari Islam dan terlibat dalam kegiatan anti-negara secara langsung.

\section{Fundamentalisme Islam}

Istilah fundamentalisme muncul dari luar tradisi sejarah Islam, dan pada mulanya merupakan gerakan keagamaan yang timbul di kalangan kaum Protestan di Amerika Serikat pada 1920-an. Menilik asal-usulnya ini, kita dapat mengatakan bahwa fundamentalisme sesungguhnya sangat tipikal Kristen. ${ }^{6} \mathrm{Namun}$, terlepas dari latar belakang Protestan-nya, istilah fundamentalisme sering digunakan untuk menunjuk fenomena keagamaan yang memiliki kemiripan dengan karakter dasar fundamentalisme Protestan. Karena itu, kita dapat menemukan fenomena pemikiran, gerakan dan kelompok fundamentalis di semua agama, seperti fundamentalisme Islam, Yahudi, Hindu, dan Budhisme. ${ }^{7}$ Dalam hal ini, selain fundamentalisme tidak terbatas pada agama tertentu, dalam faktanya ia juga tidak hanya muncul di kalangan kaum miskin dan tidak terdidik. Fundamentalisme dalam bentuk apapun bisa muncul di mana saja ketika orang-orang melihat adanya kebutuhan untuk melawan budaya sekular (godless), bahkan ketika mereka harus menyimpang dari ortodoksi tradisi mereka untuk melakukan perlawanan itu.

Berdasarkan pengamatannya terhadap fundamentalisme agama, terutama Kristen di Amerika, Peter H uff mencatat ada enam karakteristik penting fundamentalisme. Secara sosiologis, fundamentalisme sering dikaitkan dengan nilai-nilai yang telah ketinggalan zaman atau tidak relevan lagi dengan perubahan dan perkembangan zaman; secara kultural, fundamentalisme menunjukkan kecenderungan kepada sesuatu yang vulgar dan tidak-tertarik pada hal-hal yang bersifat intelektual; secara psikologis, fundamentalisme ditandai dengan otoritarianisme, arogansi, dan lebih condong kepada teori konspirasi. Secara intelektual, fundamentalisme dicirikan oleh tiadanya kesadaran sejarah dan ketidak-mampuan terlibat dalam pemikiran kritis; dan secara teologis, fundamentalisme diidentikkan dengan literalisme, primitivisme, legalisme dan tribalisme; sedangkan secara politik, fundamentalisme dikaitkan dengan populisme reaksioner. ${ }^{8}$

\footnotetext{
${ }^{4}$ Saad Eddin Ibrahim, "Anatomy of Egypt's M ilitant Islamic G roup: Methodological Note and Preliminary Findings," International J ournal of Middle East Studies 12, 4 (1980): 427. Military Academy didirikan atas inisiatif Salih Siriyya, seorang Palestina terpelajar dengan gelar Ph.D di bidang sains, anggota Ikhwan al-Muslimin cabang J ordania, yaitu Hizb al-Tahrir al-Islami. Ibrahim menemukan adanya kemiripan dalam basis sosiologis antara Military Academy (MA), Takfir wa al-Hijrah, Ikhwan al-Muslimin dan Mujahidin (Iran) menyangkut usia, latar belakang pendidikan, latar belakang desa dan kota kecil dan afiliasi kelas. Selain itu, MA dan Mujahidin sama-sama menggunakan kekerasan untuk menggulingkan rejim penguasa yang mereka anggap sekular, tidak Islami.

${ }^{5}$ Ayubi, Political Islam: Religion and Politics in the Arab World, 67-68.

${ }^{6}$ Lihat William Shepard, "Fundamentalism Christian and Islamic," Religion 17 (1987): 355-378.

7 William Shepard, “What is 'Islamic Fundamentalism'?," Studies in Religion 17, 1 (1988): 5-25.

${ }^{8} \mathrm{Huff}$, "The Challenge of Fundamentalism for Interreligious Dialogue," Cross Current (Spring-Summer, 2002). Diakses dari http://www.findarticles.com/cf_0/m2096/2000_Spring-Summer/63300895/print.jhtml
} 
Dalam kasus Islam, fundamentalisme muncul sebagai reaksi terhadap akibat-akibat yang ditimbulkan oleh modernisme dan sekularisme dalam kehidupan politik dan keagamaan. Peradaban modern-sekular menjadi sasaran kritik fundamentalisme Islam, dan di sini fundamentalsime memiliki fungsi kritik. Seperti ditipologikan oleh Fazlur Rahman, fundamentalisme Islam (atau revivalisme Islam) merupakan reaksi terhadap kegagalan modernisme Islam (klasik), karena ternyata yang disebut terakhir ini tidak mampu membawa masyarakat dan dunia Islam kepada kehidupan yang lebih baik, sesuai dengan ajaran Islam. Sebagai gantinya, fundamentalisme Islam mengajukan tawaran solusi dengan kembali kepada sumber-sumber Islam yang murni dan otentik, dan menolak segala sesuatu yang berasal dari warisan modernisme Barat. ${ }^{9}$

Salah satu karakteristik atau ciri terpenting dari fundamentalisme Islam ialah pendekatannya yang literal terhadap sumber Islam (al-Q ur'an dan al-Sunnah). Literalisme kaum fundamentalis tampak pada ketidak-sediaan mereka untuk melakukan penafsiran rasional dan intelektual, karena mereka -kalau-lah membuat penafsiran- sesungguhnya adalah penafsir-penafsir yang sempit dan sangat ideologis. Literalisme ini berkoinsidensi dengan semangat skripturalisme, meskipun Leonard Binder membuat kategori fundamentalisme non-skriptural untuk pemikir fundamentalis seperti Sayyid Qutb. ${ }^{10}$

Olivier Roy membedakan antara fundamentalisme Islam tradisional dan modern. Fundamentalisme tradisional ('ulama) dicirikan oleh kuatnya peran ulama atau oligarki klerikal (clerical oligarchy) dalam membuat penafsiran terhadap Islam, terutama Shiłah. Islam Shîsah memberikan otoritas sangat besar kepada 'ulama untuk menafsirkan doktrin agama. Tafsir mereka pun bersifat absolut. Akibatnya, kebebasan intelektual untuk menafsirkan teks-teks agama menjadi sangat sempit dan terbatas. ${ }^{11}$ Dapat dinyatakan bahwa salah satu faktor yang mendukung berkembangnya fundamentalisme (tradisional) adalah kuatnya otoritas 'ulama, termasuk dalam hal-hal yang berkaitan dengan kehidupan sosial dan politik. Dalam hal ini, tampak adanya kemiripan antara fundamentalisme di satu pihak dan tradisionalisme di pihak lain.

Fundamentalisme tradisional menganggap 'ulama dan penguasa politik merupakan dua entitas yang terpisah; masalah agama berada di tangan kaum klerikal, sementara negara berada di tangan figur sekular -presiden, raja. Karenanya, tidak ada teokrasi dalam Islam, kecuali dalam kasus wilâyat al-faqîh di Iran.

Sedangkan fundamentalisme modern atau neo-fundamentalisme dicirikan oleh orientasi yang kuat kepada politik dengan menjadikan Islam sebagai ideologi. Islam tidak dipahami sebagai agama yang memuat doktrin tentang ritual, tetapi ditafsirkan sebagai ideologi yang diperhadapkan dengan ideologi modern seperti kapitalisme, liberalisme atau sosialisme. Roy mengidentifikasi Islamisme sebagai bentuk lebih mutakhir dari neo-fundamentalisme. Fundamentalisme Islam modern tidak dipimpin oleh ulama (kecuali di Iran), tetapi oleh "intelektual sekular" yang secara

\footnotetext{
${ }^{9}$ Fazlur Rahman, Islam, second edition (Chicago: The University of Chicago Press,1979), 222-223; J uga lihat Fazlur Rahman, "Roots of Islamic Neo-Fundamentalism," in Change in the Muslim World, ed. Philip H Stoddard, David C. Cuthell and Margaret V. Sullivan (Syracuse: Syracuse University Press, 1981).

${ }^{10}$ Lihat Leonard B inder, Islamic Liberalism (Chicago: The University of Chicago Press, 1988).

${ }^{11}$ Olivier Roy, The Failure of Political Islam, trans. Carol Volk (Cambridge, Massachusetts: H arvard University Press, 1994), 12 dan 75.
} 
terbuka mengklaim sebagai pemikir religius. Mereka berpendapat bahwa karena semua pengetahuan itu bersifat ilahi dan religius; maka ahli kimia, teknik, insinyur, ekonomi, ahli hukum adalah ulama. ${ }^{12} \mathrm{~J}$ adi, terdapat semacam anti-clericalism di kalangan fundamentalisme Islam modern, meskipun fundamentalisme dalam wajahnya yang lain juga dicirikan oleh adanya oligarki klerikal seperti disebut terdahulu.

Fundamentalisme Islam adalah respons terhadap tantangan dan akibat yang ditimbulkan oleh modernisasi, dan bertujuan untuk menawarkan ideologi Islam terhadap dunia sekularmodern. Islam dijadikan sebagai alternatif pengganti ideologi modern, seperti liberalisme, Marxisme dan nasionalisme. Karena fundamentalisme bukanlah gerakan keagamaan per se, tetapi lebih dari itu adalah gerakan politik yang memperjuangkan suatu sistem kenegaraan yang didasarkan pada Islam (shariłah), dapat dipahami mengapa kebanyakan pemimpin fundamentalis adalah kaum intelektual tanpa pendidikan sistematik dalam studi Islam. Dengan ungkapan lain, mereka bukanlah teolog, tetapi pemikir sosial dan aktifis politik. ${ }^{13}$ Ini sangat tampak terutama dalam tradisi fundamentalisme Sunni.

Meskipun dalam faktanya fundamentalisme Islam modern merupakan kelompok minoritas di dunia Islam, mereka menikmati dan memainkan peranan politik yang signifikan di banyak negara Muslim. Namun demikian, aktifitas mereka tidak diorganisasikan dari satu pusat, sehingga tidak jarang program, strategi dan taktik mereka berbeda dari satu negara ke negara lain. Dalam hal ini, fundamentalisme dicirikan oleh proliferasi kepemimpinan dan polycentrisme. Namun, keragaman ini tidak menghilangkan adanya beberapa agenda, tema dan kebijakan bersama yang didukung oleh kaum fundamentalis Islam modern. Bagi fundamentalis Islam modern, negara Islam adalah negara ideologis yang domainnya mencakup seluruh kehidupan manusia. Negara Islam mengontrol relasi sosial, politik, ekonomi dan kultural, dan negara harus didasarkan pada hukum atau sharisat Islam (ideologi Islam).

Meskipun kaum fundamentalis meyakini sifat religius mereka, fundamentalisme sesungguhnya bukanlah sebuah pilihan untuk menjadi religius, melainkan sebagai corak pemikiran yang menyimpang dari arus utama (mainstream), anti-modernisme, anti-rasionalisme, anti-intelektualisme dan karakter-karakter lain yang memiliki konotasi negatif. Dalam politik, fundamentalisme dipandang sebagai ancaman bagi demokrasi, liberalisme dan pluralisme.

\section{Fundamentalisme dan Revivalisme}

Yang agak problematik dalam konteks ini adalah korelasi antara fundamentalisme dan revivalisme. Penulis-penulis seperti Youssef Chouieri, R. H rair Dekmejian dan J ohn O bert Voll memiliki perspektif yang beragam dalam melihat fenomena fundamentalisme dan revivalisme. Chouieri menyatakan bahwa munculnya revivalisme Islam dilatar-belakangi oleh kemerosotan moral, sosial dan politik umat Islam. Menurutnya, revivalisme Islam hendak menjawab

\footnotetext{
${ }^{12}$ Roy, The Failure of Political Islam, 75.

${ }^{13}$ Anwar-ul-H aq Ahady, "The Decline of Islamic Fundamentalism," J ournal of Asian and African Studies XXVII, 34 (1992): 231. J uga Abdel Salam Sidahmed dan Anoushiravan Ehteshami (eds), Islamic Fundamentalism (B oulder, Colorado: Westview Press Inc., 1996), 3; mengutip Martin E. Marty dan R. Scott Appleby, Fundamentalism Observed (The Fundamentalism Project) (Chicago: The University of Chicago Press, 1990).
} 
kemerosotan Islam dengan kembali kepada ajaran Islam yang murni. Contoh dari gerakan Islam revivalis adalah Wahhabiyah yang memperoleh inspirasi dari Muhammad b. 'Abd al-Wahhab (1703-1792) di Arabia, Shah Wali Allah (1703-1762) di India, Uthman Dan Fodio (1754-1817) di Nigeria, Gerakan Padri (1803-1837) di Sumatra, dan Sanusiłah di Libya yang dinisbatkan kepada Muhammad 'Ali al-Sanusi (1787-1859). Chouieri melihat adanya kemiripan agenda yang menjadi karakteristik gerakan-gerakan revivalis Islam tersebut, yaitu: (a) kembali kepada Islam yang asli, memurnikan Islam dari tradisi lokal dan pengaruh budaya asing; (b) mendorong penalaran bebas, ijtihad, dan menolak taqlid; (c) perlunya hijrah dari wilayah yang didominasi oleh orang kafir (dapal-kufr); (d) keyakinan kepada adanya pemimpin yang adil dan seorang pembaru. ${ }^{14}$

Sementara itu, Dekmejian menyatakan bahwa munculnya pelbagi orientasi ideologi revivalis Islam dipengaruhi oleh adanya perbedaan yang timbul dari penafsiran yang berbeda terhadap al-Q ur'an, al-Sunnah dan sejarah Islam awal. Selain itu ada faktor lain seperti watak dari situasi krisis, keunikan dalam kondisi sosial dan gaya kepemimpinan dari masing-masing gerakan. Atas dasar itu, Dekmejian mengidentifikasi empat kategori ideologi revivalis: (a) adaptasionis-gradualis (al-Ikhwan al-M uslimun di Mesir, Iraq, Sudan, J ordan, Afrika Utara; dan J ama'at-i Islami di Pakisan); (b) Shi'ah revolusioner (Republik Islam Iran, H izb al-Da'wah Iraq, Hizbullah Libanon, J ihad Islam Libanon; (c) Sunni revolusioner (al-J ihad Mesir, Organisasi Pembebasan Islam Mesir, J ama'ah Abu Dharr Syria, Hizb al-Tahris di J ordania dan Syria; (d) primitivis-Mesianis (al-Ikhwan Saudi A rabia, al-Takfiswa al-Hijrah Mesir, Mahdiyah Sudan, J ama'at al-Muslimin li al-Takfis Mesir. ${ }^{15}$

Voll cenderung tidak membuat pembedaan yang signifikan antara revivalisme dan fundamentalisme. Menurutnya, Islamic revivalism atau Islamic resurgence mewujudkan dirinya dalam bentuk yang beragam, misalnya Wahhabiłah, yang dia anggap sebagai representasi dari "the prototype of rigorous fundamentalism in the modern Islamic experience,"16 yang oleh Choueiri dipandang sebagai revivalis dalam makna yang positif, seperti disebut terdahulu.

Terlepas dari beberapa perbedaan perspektif dan implikasi yang ditimbulkannya, korelasi, kaitan atau kemiripan karakteristik dasar antara fundamentalisme, revivalisme, Islamisme dan radikalisme tidak bisa dikesampingkan. J ika ditelaah lebih mendalam akan tampak adanya semacam family resemblance antara berbagai orientasi ideologis tersebut, ${ }^{17}$ meskipun masingmasing tetap memiliki tekanan dan strategi yang berbeda, tergantung situasi dan kondisi sosial dan gaya kepemimpinan (leadership style) dari masing-masing gerakan.

\footnotetext{
${ }^{14}$ Youssef M. Choueiri, Islamic Fundamentalism (Boston, Massachusetts: Twayne Publishers, 1990), 21-24.

${ }^{15}$ R. Hrair Dekmejian, "Islamic Revival: Catalysts, Categories, and Consequences," dalam The Politics of Islamic Revivalism: Diversity and Unity, ed. Shireen T. H unter (Bloomington and Indianapolis: Indiana University Press, 1988), 12.

${ }^{16} \mathrm{~J}$ ohn Obert Voll, Islam Continuity and Change in the Modern World, Second Edition (Syracuse: Syracuse University Press, 1994), 53; J ohn Obert Voll, "Relations Among Islamist G roups," dalam Political Islam: Revolution, Radicalism, or Reform?, ed. J ohn L. Esposito (Boulder, Colorado: Lynne Rienner Publishers, Inc., 1997): 231-247.

${ }^{17}$ U ntuk kajian tentang perbandingan karakteristik orientasi ideologi gerakan Islam (tradisionalis, modernis, sekularis dan fundamentalis), lihat Achmad J ainuri, Orientasi Ideologi Gerakan Islam (Surabaya: LPAM, 2004).
} 


\section{Neo-Fundamentalisme dan Islam Politik (Political Islam)}

Mengikuti penjelasan Ayubi dan Roy di atas, fundamentalisme Islam juga sering digunakan untuk menunjuk aspirasi Islam politik (political Islam). Ini tidak terlepas dari beberapa agenda fundamentalis di bidang politik. Watak politis fundamentalisme Islam termanifestasikan dalam simbol-simbol keagamaan yang mereka gunakan dalam konteks perjuangan politik atau kekuasaan, misalnya negara Islam, pemerintahan Islam dan formalisasi shari ‘ah dalam negara. Salah satu doktrin Islam fundamentalis - dan pelbagai varian di dalamnya - adalah bahwa tidak ada pemisahan agama dari politik. Olivier Roy menyebut paham ini sebagai Islamic political imagination (imajinasi politik Islam). ${ }^{18}$ Menurut Roy, fundamentalisme ini tampak pada Ikhwan al-M uslimin di M esir yang didirikan oleh $\mathrm{H}$ \&san al-Banna>dan J amałat-i Islamizdi Indo-Pakistan yang didirikan oleh Abû al-A'la>al-Mawdudi>Keduanya mendefinisikan Islam sebagai sistem politik (ideologi) vis-à-vis ideologi-ideologi besar abad ke-20.

Eskpresi kontemporer dari fundamentalisme Islam adalah Hizb al-Tahris al-Islamisyang didirikan oleh Taqizal-Din al-Nabhanił (w.1977) di J erussalem pada 1953. Sejak awal gerakan ini bersaing dengan Ikhwar al-Muslimiя. Gerakan ini sangat unik karena ia mendeklarasikan diri secara terbuka sebagai partai politik yang menjadikan Islam sebagai ideologi dan bergerak dalam lapangan politik. Ia bertujuan untuk membangun kembali khilafah Islam sebagai sebuah sistem tunggal, dan tidak terpecah-pecah ke dalam negara-bangsa. Khilafah didasarkan kepada sharisah, tidak pada demokrasi sekular. Gerakan ini tergolong radikal dan revolusioner, karena ia menggunakan strategi jihad. Menurut gerakan ini, seluruh negara di dunia saat ini tidak menerapkan Islam (shariłah), karena itu merupakan dasal-kufr, meskipun penduduknya Muslim. la menekankan bahwa restorasi khilafah adalah tugas seluruh umat Muslim di dunia melalui agitasi politik dan revolusi kekhalifahan (caliphal revolution). ${ }^{19}$

Namun demikian, idealisme pelbagai kelompok Islam politik ternyata gagal mengubah landscape politik Timur Tengah dan beberapa kawasan lainnya. Islam politik tidak berhasil meraih kekuasaan, sementara rejim-rejim lama masih terus berkuasa. Kekuatan Barat dan Amerika pun semakin menancapkan hegemoni (politik, ekonomi, budaya) di kawasan tersebut. Islam politik juga tidak selalu berhasil menampilkan nilai-nilai yang terkandung dalam cita-cita fundamentalisme berupa penerapan hukum-hukum agama (sharisah) dalam politik. Kaum Islam fundamentalis di beberapa tempat, seperti di Aljazair, Sudan atau Turki, hanya melahirkan perubahan-perubahan yang tidak signifikan di bidang hukum, politik dan ekonomi. Dalam hal ini, fundamentalisme memang menekankan penerapan sharisah secara total, tetapi seringkali tidak mempedulikan watak sistem politik.

Dalam realitasnya fundamentalisme bukan merupakan realitas yang monolitik, tetapi mengandung varian-varian yang beragam, dan bahkan mengalami pergeseran-pergeseran yang cukup signifikan. Selain terdapat varian fundamentalisme tradisional dan fundamentalisme modern seperti disebutkan di muka, dapat disaksikan pula adanya pergeseran kepada apa yang disebut sebagai neo-fundamentalisme.

${ }^{18}$ Roy, The Failure of Political Islam, 75.

${ }^{19}$ Ayubi, Political Islam: Religion and Politics in the Arab World, 96-97; Dale F. Eickelman dan J ames Piscatori, Muslim Politics (Princeton, N ew J ersey: Princeton University Press, 1996), 139. 
Kaum fundamentalis pada mulanya tertarik bergerak dalam level politik negara. Mereka menawarkan formula-formula dan struktur politik kenegaraan yang diderivasi dari al-Qur'an dan al-Sunnah. Bahkan, untuk mewujudkan ideal-ideal tersebut kaum fundamentalis juga membentuk partai-partai dalam kerangka demokrasi modern maupun dengan jalan revolusi. Namun, ketika mereka mengalami kegagalan politik, sasaran perjuangan kaum fundamentalis tidak lagi pada level negara, tetapi bergeser ke individu dan masyarakat. Neo-fundamentalisme lebih memfokuskan upaya pengisian kehidupan sehari-hari dengan moralitas dan sharisah (legalism). Karenanya, diskursus negara digantikan oleh diskursus masyarakat, dan strategi yang dipilih meliputi salah satu dari berikut ini: menyusup ke dalam kehidupan politik resmi, reinvestasi dalam lapangan sosial, dan moral, atau ekonomi dan pembentukan kelompokkelompok kecil, baik kelompok ultra ortodoks atau kelompok teroris. ${ }^{20}$

Orientasi dan strategi kelompok neo-fundamentalisme adalah menguasai masyarakat melalui tindakan sosial. J auh dari kesan revolusioner, kaum neo-fundamentalis sekarang masuk ke civil society dan kelas-kelas politik. Meski watak revolusi hilang, simbol-simbol Islam merembes ke masyarakat dan diskursus politik Islam. Mundurnya (retreat) fundamentalis Islam dari politik dibarengi dengan meningkatnya Islam sebagai fenomena sosial dan moral. Neo-fundamentalisme berusaha me-reislamisasi masyarakat pada tingkat akar rumput (grassroot), dan tidak lagi lewat negara. Ini konsisten dengan apa yang diyakini oleh kaum fundamentalis: jika masyarakat Islam didasarkan pada kebaikan anggota-anggotanya, maka individu-individu dan praktik mereka harus diperbarui. Kaum fundamentalis model ini mengarahkan perjuangannya pada lahirnya masyarakat Islam dan ruang Islami (Islamized space). ${ }^{21}$

Namun, pergeseran ini dipandang sebagai simbol kegagalan fundamentalisme Islam dalam politik yang berakibat pada terjadinya perubahan signifikan dalam bobot pemikiran dan gerakannya. Roy menyebut fenomena ini sebagai lumpenization, yang melahirkan lumpenintelligentsia. ${ }^{22}$ Kualitas intelektual dari kaum fundamentalis mengalami kemerosotan, aktivisme politik juga mengalami penurunan. Kaum neo-fundamentalis lebih menekankan islamized space yang otonom, dan lebih menekankan i'tikad baik individu, tanpa perlu dengan susah payah melibatkan diri dalam perjuangan politik. Di Indonesia, fenomena fundamentalisme baru ini tampak dalam Front Pembela Islam (FPI) atau Lasykar J ihad dan gerakan-gerakan radikal sejenis. Tidak jarang kaum fundamentalisme model ini juga memakai cara-cara yang mengarah kepada kekerasan.

Tampaknya, kaum Islamis beranggapan bahwa masyarakatakan terislamisasi hanya melalui tindakan sosial dan politik. Gerakan Islamis harus terjun ke lapangan politik. Kelompok Islamis menyatakan bahwa politik dimulai dari prinsip bahwa Islam adalah sistem pemikiran global. Islamis tidak dipimpin oleh 'ulama (kecuali di Iran), tetapi oleh intelektual sekular yang menyatakan diri sebagai pemikir religius. Islamis mengadopsi visi klasik Islam sebagai sistem universal dan lengkap. Karena itu Islam tidak harus dimodernisasi, justru sebaliknya kehidupan

\footnotetext{
${ }^{20}$ Roy, The Failure of Political Islam, 90-93.

${ }^{21} \mathrm{lbid}$.

22 lbid., 83.
} 
modern harus diislamisasi. Gerakan Islamis melihat dirinya sebagai gerakan sosio-politik, dibangun di atas dasar Islam yang dipahami lebih sebagai ideologi politik. Karena itu mereka tidak memperhadapkan diri dengan agama lain, tetapi lebih dengan ideologi-ideologi modern seperti Marxisme, kapitalisme, dan liberalisme.

\section{Radikalisme (Islam Militan)}

Fundamentalisme Islam dapat mengekspresikan orientasi radikal. Radikal Islam memahami Islam sebagai agama yang sempurna dan lengkap, dan memberikan perhatian kepada otentisitas kultural. Namun Islam bukanlah agama dalam pengertian Barat, tetapi Islam adalah cara hidup yang sempurna yang mengatur seluruh aspek kehidupan manusia. Posisi ini berbeda dari kaum sekularis yang menolak intervensi agama dalam kehidupan publik, terutama politik. Manifestasi dari pandangan radikal adalah pada keharusan untuk mendirikan negara Islam yang didasarkan pada shari ah. Perbedaan antara kaum radikal dan modernis adalah penegasan yang pertama terhadap keunikan Islam. Mereka dengan tegas menolak setiap usaha untuk mengidentifikasi Islam dengan demokrasi, kapitalisme, sosialisme atau ideologi Barat lainnya. ${ }^{23} \mathrm{H}$ anya saja, berbeda dari Islamis atau neo-fundamentalis, radikalisme Islam memperbolehkan penggunaan cara kekerasan atau bahkan pembunuhan untuk mewujudkan agenda dan tujuan politiknya.

Radikalisme Islam merupakan fenomena modern dan kontemporer, dan merupakan reaksi terhadap munculnya nasionalisme sekular. J ika revivalisme Islam mendapatkan inspirasi dari ide-ide normatif Islam, dan reformisme berusaha untuk menggabungkan unsur-unsur Islam dan Barat, ideologi radikalisme menggambarkan respons langsung terhadap munculnya negarabangsa yang merdeka. Militansi dan atavisme radikalisme Islam menggambarkan sintesis kreatif revivalisme dan reformisme. ${ }^{24}$

\section{Fundamentalisme Islam di Indonesia: Mapping Pendahuluan}

Dalam konteks Indonesia, pemetaan orientasi ideologi gerakan Islam membutuhkan observasi dan identifikasi yang mendalam. Namun, jika kita mengikuti pendekatan Olivier Roy atau Nazih Ayubi, maka fundamentalisme Islam di Indonesia memiliki karakteristik dasar yang tidakjauh berbeda dari rekannya di kawasan Timur Tengah misalnya, meskipun terdapat keunikan dan paradoks-paradoks.

Fundamentalisme Islam di Indonesia dapat dibedakan menjadi dua: tradisional dan modern. Fundamentalisme tradisional diwakili oleh kelompok yang menekankan pendekatan literal dan skriptural terhadap sumber Islam, seperti Persatuan Islam (Persis), dan dalam konteks mutakhir Majelis Ulama Indonesia (MUI) melalui fatwa-fatwanya. ${ }^{25}$

Sementara itu, fundamentalisme modern atau neo-fundamentalisme dalam politik diwakili misalnya oleh partai politik Islam seperti Partai Keadilan Sejahtera (PKS), Partai Bulan Bintang (PBB), dan partai-partai Islam lain yang bercita-cita mendirikan "negara Islam" dengan dasar

\footnotetext{
${ }^{23}$ William Shepard, “What is 'Islamic Fundamentalism'?," Studies in Religion 17, 1 (1988): 11.

${ }^{24}$ Choueiri, Islamic Fundamentalism, 70.

${ }^{25}$ Lihat misalnya Kompas 30 J uli 2005, 1, 4-5; Tempo (21 Agustus 2005), 156-157.
} 
shariłah dan ideologi Islam. Mereka yang memperjuangkan Piagam J akarta sebagai dasar negara termasuk dalam kelompok fundamentalisme atau neo-fundamentalisme. Mereka tidak mempersoalkan watak negara-bangsa dengan demokrasi sekularnya. Namun, secara substansial sesungguhnya terdapat paradoks antara penerimaan mereka terhadap sistem politik sekular dengan perjuangan mereka menerapkan sharißat Islam. Jadi, ditemukan adanya sikap kompromistis atau bahkan pragmatis di kalangan kelompok fundamentalis Islam ini, tidak lagi sebagai taktik politik.

Contoh fundamentalisme Islam lainnya adalah Hizbut-Tahrir Indonesia ( $\mathrm{HTI}$ ) yang memperjuangkan berdirinya khilafah universal dan shariłah Islam sebagai dasarnya. Kelompok ini tidak mengakui negara nasional. Perjuangan mereka tidak untuk mendirikan negara Islam di Indonesia, seperti partai politik Islam yang ada, tetapi membangun negara Islam trans-nasional di bawah kepemimpinan tunggal khilafah Islamiłah. Hampir serupa dengan HTI adalah gerakan J ama'ah Islamiłah yang dianggap bertujuan untuk mendirikan negara regional (Asia Tenggara) di bawah kepemimpinan seorang amir. Sangat mungkin, Majelis Mujahidin Indonesia (MMI) merepresentasikan model gerakan ini. Baik HTI maupun MMI memiliki kesamaan dalam orientasi politiknya dan sama-sama menolak rejim sekular, demokrasi dan hegemoni Barat (Amerika). ${ }^{26}$ Meminjam Roy, mereka ini adalah kelompok political Islam (Islam politik) yang belum pernah berhasil mengubah landscape politik.

Sementara itu, ekspresi fundamentalisme Islam yang lain adalah orientasi radikalisme Islam yang terwakili misalnya oleh gerakan Front Pembela Islam (FPI), dan Lasykar J ihad. O rientasi radikalisme Islam ini lebih pada penerapan sharisah pada tingkat masyarakat, tidak pada level negara. Dengan mengikuti penjelasan Roy terdahulu, orientasi ini menggambarkan adanya pergeseran perjuangan kaum fundamentalis dari pengislaman negara (formalisasi sharisah pada level negara) ke pengislaman (penerapan shariłah pada level) masyarakat. Mereka berjuang tidak untuk mewujudkan negara Islam (setidak-tidaknya untuk jangka pendek), tetapi lebih pada penerapan sharisah pada level keluarga dan masyarakat (Islamized space). Hanya saja, dalam mewujudkan tujuan Islamisasi masyarakat, menjaga moralitas Islam, mereka cenderung menggunakan cara atau pendekatan kekerasan.

\section{Daftar Rujukan}

Abaza, Mona. "The Discourse on Islamic Fundamentalism in the Middle East and Southeast Asia: A Critical Perspective," Sojourn 6 (1991): 203-239.

Abdel Salam Sidahmed dan Anoushiravan Ehteshami (eds). Islamic Fundamentalism. Boulder, Colorado: Westview Press Inc., 1996.

Ahady, Anwar-ul-H aq. "The Decline of Islamic Fundamentalism," J ournal of Asian and African Studies XXVII, 3-4 (1992): 231.

\footnotetext{
${ }^{26}$ Lihat Riza Sihbudi, et.al. Islam dan Radikalisme di Indonesia (J akarta: LIPI Press, 2005). Karya ini merupakan hasil riset tentang gerakan-gerakan fundamentalis atau radikal Islam di Indonesia, seperti MMI, HTI, J amaah Salafi Bandung, FPI Surakarta dan Komite Persiapan Penegakan Syariat Islam Sulawesi Selatan.
} 
Ayubi, Nazih. Political Islam: Religion and Politics in the Arab World. London and New York: Routledge, 1991.

Binder, Leonard. Islamic Liberalism. Chicago: The University of Chicago Press, 1988.

Choueiri, Youssef M. Islamic Fundamentalism. Boston, Massachusets: Twayne Publishers, 1990. Dekmejian, R. H rair. "Islamic Revival: Catalysts, Categories, and Consequences." Dalam The Politics of Islamic Revivalism: Diversity and Unity, ed. Shireen T. H unter. 3-19. Bloomington and Indianapolis: Indiana University Press, 1988.

Eickelman, Dale F. dan James Piscatori. Muslim Politics. Princeton, New J ersey: Princeton University Press, 1996.

H uff, Peter. "The Challenge of Fundamentalism for Interreligious Dialogue," Cross Current (Spring-Summer, 2002). http://www.findarticles.com/cf_0/m2096/2000_Spring-Summer/ 63300895/print.jhtml

Ibrahim, Saad Eddin. "Anatomy of Egypt's Militant Islamic Group: Methodological Note and Preliminary Findings." International J ournal of Middle East Studies 12, 4 (1980): 423453.

J ainuri, Achmad. Orientasi Ideologi Gerakan Islam. Surabaya: LPAM, 2004.

Rahman, Fazlur. "Roots of Islamic Neo-Fundamentalism." Dalam Change in the M uslim World, ed. Philip H Stoddard, David C. Cuthell and Margaret V. Sullivan (Syracuse: Syracuse University Press, 1981.

Rahman, Fazlur. Islam. Second Edition. Chicago: The University of Chicago Press,1979.

Roy, Olivier. The Failure of Political Islam. Trans. Carol Volk. Cambridge, Massachusetts: Harvard University Press, 1994.

Shepard, William. "Fundamentalism Christian and Islamic," Religion 17 (11987): 355-378.

Shepard, William. “What is 'Islamic Fundamentalism'?," Studies in Religion 17, 1 (1988): 5-25. Sihbudi, Riza, et.el. Islam dan Radikalisme di Indonesia. J akarta: LIPI Press, 2005.

Sivan, Emmanuel. Radical Islam: Medieval Theology and Modern Politics. Enlarged Edition. New Haven and London: Yale University Press, 1985.

Voll, J ohn Obert. "Relations Among Islamist Groups," dalam Political Islam: Revolution, Radicalism, or Reform?. Ed. John L. Esposito. Boulder, Colorado: Lynne Rienner Publishers, Inc., 1997, 231-247.

Voll, J ohn O bert. Islam Continuity and Change in the Modern World. Second Edition. Syracuse: Syracuse University Press, 1994. 